\title{
Analisis Kesalahan Siswa SMA dalam Menyelesaikan Soal Integral
}

\author{
Sindi Amelia ${ }^{1}$, Gusri Yadrika²
}

\begin{abstract}
Abstrak: Rendahnya prestasi siswa dalam menyelesaikan soal integral harus ditanggapi oleh para guru, karena integral merupakan materi yang aplikatif di berbagai bidang ilmu. Dengan menganalisis jenis-jenis kesalahan siswa serta mengetahui letak-letak kesalahan siswa, akan menjadi suatu evaluasi bagi guru untuk mengatasi kesalahan siswa dalam menjawab soal integral. Tujuan penelitian ini adalah untuk mendeskripsikan; (1) jenis kesalahan siswa dalam menyelesaikan soal integral, (2) penyebab kesalahan siswa dalam menyelesaikan soal integral. Jenis penelitian ini merupakan kualitatif dengan subjek penelitian adalah 10 siswa dari MA Khairul Ummah Inhu. Instrumen pengumpulan data terdiri dari soal tes integral dan lembar wawancara tidak terstruktur. Hasil penelitian menunjukkan bahwa; (1) terdapat 4 jenis kesalahan yang dilakukan siswa yaitu kesalahan konsep sebesar 36,7\%, kesalahan fakta sebesar 3,3\%, kesalahan prinsip sebesar 5\%, dan kesalahan operasi sebesar 20\%; (2) penyebab kesalahan adalah siswa kurang memahami materi pecahan sebagai prasyarat untuk materi integral. Saran yang diberikan untuk meminimalkan kesalahan siswa dalam menyelesaikan soal yaitu memberikan pemahaman me ngenai konsep materi yang menjadi prasyarat terlebih dahulu.
\end{abstract}

Kata kunci: Analisis Kesalahan, Integral

Abstract: The low achievement of students in completing integral questions must be responded by the teachers, because integrals are applicable material in various fields of science. By analyzing the types of student errors and knowing the location of student errors, it will be an evaluation for the teacher to overcome the students' mistakes in answering integral questions. The purpose of this study is to describe; (1) the types of student error in solving integral, (2) the causes of student errors in solving integral. This research method was a qualitative research. The research subjects were taken 10 students from MA Khairul Ummah Inhu. The results of the study indicated that; (1) There were 4 types of mistakes made by students, namely concept errors (36,7\%), fact errors (3,3\%), principle errors of (5\%), and operation errors (20\%); (2) A causes of errors was students did not understand the prerequisite material for the integral material. The suggestion to minimize students' mistakes in solving the problems is to provide an concept understanding of material that are prerequisites.

Keywords: Error Analysis, Integral

\section{PENDAHULUAN}

Kalkulus merupakan salah satu cabang dari ilmu matematika yang memiliki sifat aplikatif yang luas dalam bidang sains lainnya, seperti kedokteran, teknik, dan pertanian. Bidang ilmu ini juga dapat memecahkan berbagai masalah yang tidak dapat dipecahkan dengan aljabar elementer. Kalkulus merupakan payung dari materi limit, turunan, integral, dan deret tak terhingga.

Integral sebagai salah satu materi kalkulus, telah dipelajari mulai tingkat sekolah menengah atas hingga perguruan tinggi. Kemampuan yang diuji pada materi ini meliputi: (1) menghitung integral taktentu, (2) menghitung integral tertentu fungsi aljabar dan fungsi trigonometri, (3) menghitung luas daerah, dan (4) menghitung volume benda putar. Lestari, Suharto, dan Fatahillah (2016) menyatakan bahwa materi integral memiliki cakupan luas dan kadang-kadang memerlukan penyelesaian yang cukup panjang dan rumit. Beberapa hasil penelitian menunjukkan bahwa hasil belajar siswa pada materi integral di Indonesia masih tergolong rendah.Hasil penelitian Orton (dalam Ramdani, 2012) menunjukkan bahwa nilai rata-rata materi integral memiliki nilai terendah yaitu 1.895 untuk tingkat sekolah dibandingkan dengan materi dalam kalkulus lainnya seperti: barisan, limit, dan turunan.

Rendahnya hasil belajar siswa pada materi integral ini perlu dianalisis untuk menemukan jenis-jenis kesalahan yang dilakukan siswa, sehingga guru dapat memberikan solusi yang tepat dalam menyelesaikannya. Menurut Umam (2014), dengan melakukan analisis kesalahan siswa, guru mendapatkan gambaran yang jelas dan rinci atas kelemahan-kelemahan siswa dalam menyelesaikan persoalan

\footnotetext{
${ }^{1}$ Dosen Program Studi Pendidikan Matematika Universitas Islam Riau

${ }^{2}$ Mahasiswa Magister Pendidikan Matematika Universitas Riau
} 
matematika. Kesalahan yang dilakukan siswa dapat digunakan sebagai bahan pertimbangan pengajaran dalam usaha meningkatkan kegiatan belajar dan mengajar khususnya materi integral.

Terkait pada penelitian ini, analisis kesalahan siswa dalam menyelesaikan soal dibagi kedalam 4 jenis kesalahan yaitu kesalahan konsep, kesalahan fakta, kesalahan prinsip, dan kesalahan operasi. Empat komponen ini menjadi satu kesatuan yang solid dalam pembelajaran matematika. Sebagaimana pendapat Riyanto dan Siroj (2011) yang menyatakan bahwa matematika merupakan pengetahuan yang terstruktur, sistematis, tersusun secara hierarkis, dan terjalin hubungan fungsional yang erat antar komponen. Komponen-komponen tersebut adalah konsep, fakta, prinsip, dan operasi.

Tujuan utamadaripenelitian ini adalah untuk mendeskripsikanjenis kesalahan siswa dalam menyelesaikan soal integral serta menggali penyebab kesalahan siswa dalam menyelesaikan soal integral. Penulis berharap tulisan ini menjadi suatu landasan bagi para guru dan peneliti bidang pendidikan matematika dalam menerapkan strategi yang tepat dalam pembelajaran kalkulus khususnya materi integral.

\section{METODE PENELITIAN}

Penelitian ini menggunakan jenis penelitian deskriptif kualitatif dengan subjek penelitian adalah 10 siswa kelas XII di MA Khairul Ummah Inhu Tahun Pelajaran 2018/2019. Subjek penelitian terdiri dari 3 siswa dengan kemampuan tinggi, 4 siswa dengan kemampuan rendah, dan 3 siswa dengan kemampuan rendah. Instrument penelitian yang digunakan terdiri dari 6 soal essay pada materi pokok integral. Instrumen penelitian ini telah valid dan memiliki nilai reliabilitas sebesar 0,88. Menurut klasifikasi Guilford (dalam Ramdani, 2012) menyatakan bahwa koefesien reliabilitas sebesar 0,7sampai 0,9 tergolong tinggi untuk sebuah instrumen. Tes ini dilaksanakan selama \pm 90 menit.

Teknik pengumpulan data pada penelitian inimenggunakan metode tes dan wawancara tidak terstruktur. Dari jawaban siswa terhadap soal tes yang diberikan dapat ditentukan jenis-jenis kesalahan dan persentase dari masing-masing jenis kesalahan yang dilakukan. Sesuai dengan pendapat Oktavia dan Khotimah (2016) yang menyatakan bahwa kesalahan dapat dilihat dari hasil pekerjaan siswa dalam mengerjakan tes. Selanjutnya, faktor penyebab terjadinya kesalahan dapat diketahui melalui wawancara dengan siswa yang melakukan kesalahan dalam menjawab soal. Sedangkan ujikeabsahan data dilakukan dengan teknik triangulasi data.

\section{PEMBAHASAN}

Berdasarkan hasil dari tes yang diberikan pada siswa yang menjadi subjek penelitian, terdapat beberapa kesalahan dalam menjawab setiap soal yang diberikan. Untuk mengetahui persentase ketercapaian siswa pada setiap indikatornya dapat dilihat pada tabel 1 berikut ini.

Tabel 1.

Hasil Tes Siswa pada Setiap Indikator

\begin{tabular}{clcc}
\hline No & \multicolumn{1}{c}{ Indikator Pencapaian Kompetensi } & $\begin{array}{c}\text { Siswa yang } \\
\text { menjawab benar }\end{array}$ & $\begin{array}{c}\text { Persentase } \\
(\boldsymbol{\%})\end{array}$ \\
\hline 1 & $\begin{array}{l}\text { Menentukan integral tak tentu fungsial jabar dan trigonometri dengan } \\
\text { menggunakan sifat-sifat integral. }\end{array}$ & 6 & 60 \\
2 & $\begin{array}{l}\text { Menentukan integral tentu dari fungsi aljabar dengan menggunakan sifat- } \\
\text { sifat integral. }\end{array}$ & 7 & 70 \\
3 & $\begin{array}{l}\text { Menentukan integral tentu dengan menggunakan aturan subtitusi. } \\
4\end{array}$ & $\begin{array}{c}\text { Menentukan integral tentu menggunakan aturan integral parsial. } \\
\text { Menghitung luas suatu daerah yang dibatasi oleh kurva dan sumbu-sumbu } \\
\text { pada koordinat. }\end{array}$ & 60 \\
6 & Menghitung volume bendaputar. & 2 & 60 \\
\hline
\end{tabular}

Berdasarkan tabel di atas, terlihat di setiap indikator pencapaian kompetensi pada materi integral ini tidak ada persentase yang mencapai $100 \%$. Bahkan dari subjek penelitian yang ada, tidak satupun yang benar dalam menjawab soal volume benda putar (indikator 6). Pada indikator pencapaian kompetensi 1, 3, dan 4, sebanyak 4 siswa kelas XII di MA Khairul Ummah Inhu tidak berhasil menjawab dengan benar. Sedangkan indikator 5 menempatkan posisi dua terbawah (20\%) pada tingkatan persentase siswa yang 
menjawab dengan benar. Hal ini bermakna, masih banyak terdapat kesalahan-kesalahan yang dilakukan siswa dalam menjawab soal integral yang diberikan.

Setelah data diperoleh, peneliti melakukan analisis kesalahan untuk tiap soal pada 10 subjek penelitian. Peneliti menemukan bahwa setiap siswa sekurang-kurangnya melakukan 2 jenis kesalahan. Untuk lebih jelasnya, dapat dilihat pada tabel 2 berikut ini.

Tabel 2.

Jenis Kesalahan yang Dilakukan Siswa pada Setiap Soal

\begin{tabular}{|c|c|c|c|c|c|c|}
\hline \multirow{3}{*}{ Kode Siswa } & \multicolumn{6}{|c|}{ Nomor Soal } \\
\hline & 1 & 2 & 3 & 4 & 5 & 6 \\
\hline & \multicolumn{6}{|c|}{ Jenis Kesalahan Siswa } \\
\hline K1 & B & B & $\mathrm{B}$ & $\mathrm{B}$ & B & KK/ KO \\
\hline K2 & B & B & $\mathrm{B}$ & $\mathrm{B}$ & B & $\mathrm{KK} / \mathrm{KO}$ \\
\hline K3 & KK & $\mathrm{KK} / \mathrm{KO}$ & $\mathrm{KP}$ & $\mathrm{KF}$ & KK & KK \\
\hline K4 & B & B & $\mathrm{B}$ & $\mathrm{B}$ & $\mathrm{KO}$ & $\mathrm{KK} / \mathrm{KO}$ \\
\hline K5 & KK & B & $\mathrm{B}$ & $\mathrm{B}$ & $\mathrm{KO}$ & KK \\
\hline K6 & KK & B & $\mathrm{KP}$ & B & KK & KK \\
\hline K7 & B & B & KO & KO & KK & KK \\
\hline K8 & KK & $\mathrm{KK} / \mathrm{KO}$ & $\mathrm{KP}$ & KK & KK & KK \\
\hline K9 & B & B & $\mathrm{B}$ & $\mathrm{KF}$ & KK & $\mathrm{KK}$ \\
\hline K10 & B & $\mathrm{KO}$ & $\mathrm{B}$ & $\mathrm{B}$ & $\mathrm{KO}$ & $\mathrm{KK} / \mathrm{KO}$ \\
\hline
\end{tabular}

Keterangan: KK = Kesalahan Konsep; KF = Kesalahan Fakta; KP = Kesalahan Prinsip; KR = Kesalahan Operasi; B = Benar Menjawab

Adapun persentase dari masing-masing jenis kesalahan yang dilakukan siswa disajikan pada tabel 3.

Tabel 3.

Persentase dari Masing-Masing Jenis Kesalahan

\begin{tabular}{lcc}
\hline \multicolumn{1}{c}{ Jenis Kesalahan } & Persentase \\
\hline $\mathrm{KK}=$ Kesalahan Konsep & $36,7 \%$ \\
$\mathrm{KF}=$ Kesalahan Fakta & $3,3 \%$ \\
$\mathrm{KP}=$ Kesalahan Prinsip & $5 \%$ \\
$\mathrm{KO}=$ Kesalahan Operasi & $20 \%$ \\
\hline
\end{tabular}

Dari tabel 3, terlihat bahwa kesalahan yang paling besar dilakukan siswa adalah kesalahan konsep sebesar 36,7\%, diikuti oleh kesalahan operasi 16,7\% kurangnya dari kesalahan konsep. Sedangkan jenis kesalahan yang paling minimal dari subjek penelitian adalah kesalahan fakta sebesar 3,3\%. Ini berarti, kesalahan fakta tidak menjadi masalah utama bagi sebagian besar siswa dalam menyelesaikan soal.

Untuk melihat penyebab kesalahan siswa dalam menjawab soal pada setiap indikator, dapat kita lihat pada penjabaran berikut ini.

Indikator 1: Menentukan integral tak tentu fungsi aljabar dan trigonometri dengan menggunakan sifat-sifat integral. Pada indikator ini, guru memberikan sebuah fungsi aljabar dan sebuah fungsi trigonometri. Siswa diharapkan dapat menentukan integral dari fungsi tersebut dengan menggunakan sifatsifat integral.

\section{Soal 1:Tentukanlah integral dari :}

a. $\int\left(18 x^{5}-25 x^{4}+3 x^{2}\right) d x$

b. $\int(\sin 3 x+\cos x) d x$

Pada indikator 1 ini, semua siswa dapat mengerjakan soal integral dari fungsi aljabar, namun terdapat 4 orang siswa yang salah dalam menentukan integral dari fungsi trigonometri. Salah satu jawaban siswa dapat kita lihat pada gambar-1 di bawah ini. 


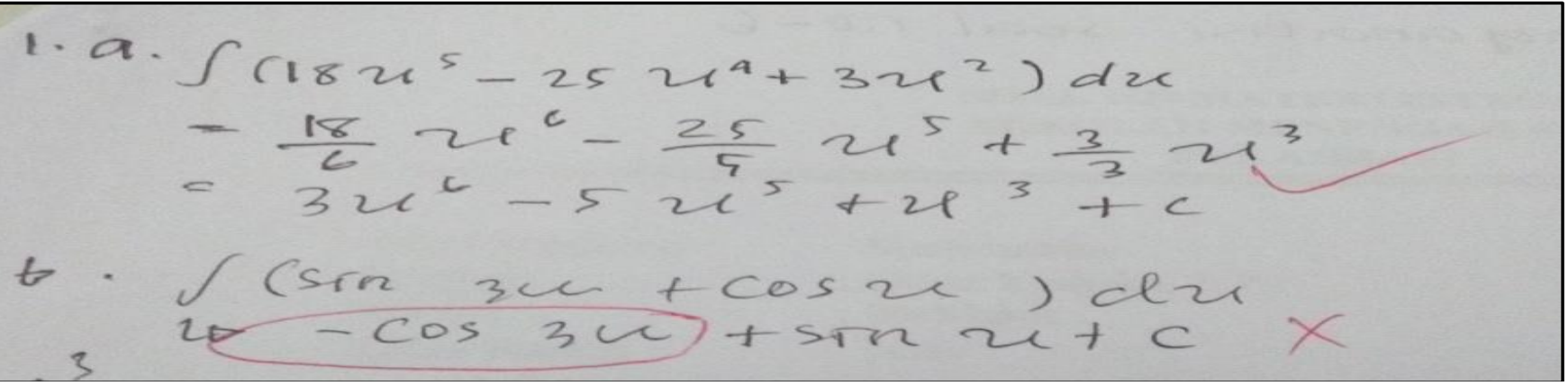

Gambar-1.

Jawaban subjek K3 pada soal nomor 1

Dari jawaban yang ditulis, terlihat siswa belum memahami konsep integral dengan baik. Siswa langsung menuliskan integral dari $\sin 3 x$ adalah $-\cos 3 x$. Artinya, siswa belum memahami sifat-sifat integral trigonometri dengan baik. Dari kasus yang seperti ini, guru diharapkan untuk membimbing kembali siswa mempelajari sifat-sifat integral.

Indikator 2: Menentukan integral tentu dari fungsi aljabar dengan menggunakan sifat-sifat integral. Pada indikator ini, guru memberikan sebuah fungsi aljabar, siswa diharapkan dapat menentukan integral tentu dari fungsi tersebut dengan menggunakan sifat-sifat integral.

Soal 2: Hasil dari $\int_{1}^{3}\left(\frac{1}{2} x^{2}+3 x\right) d x$ adalah....

Dari 10 siswa yang mengerjakan, terdapat 3 siswa yang keliru dalam menentukan integralnya. Salah satu jawaban siswa yang salah dapat kita lihat pada gambar-2 berikut ini.

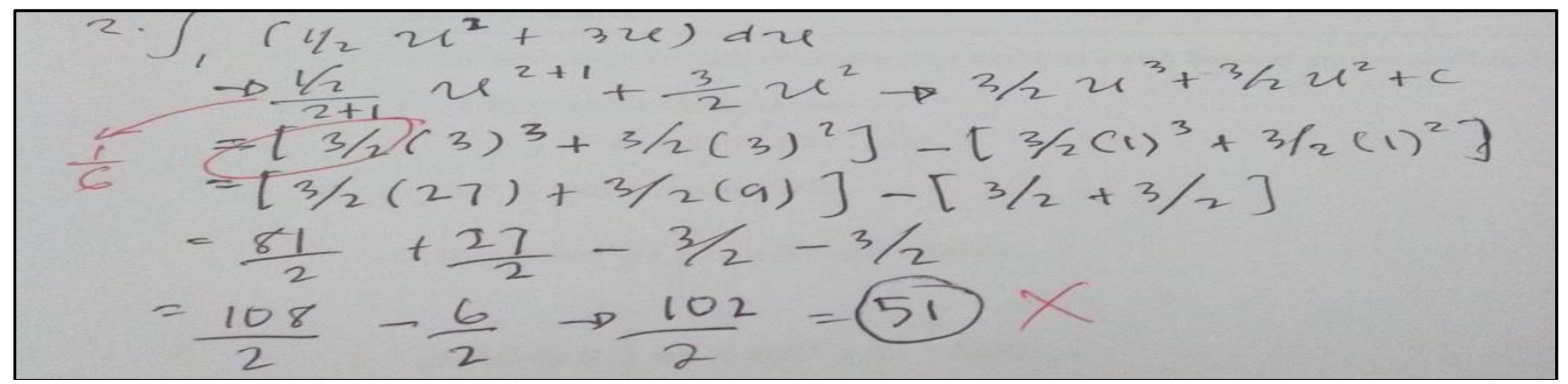

Gambar-2.

Jawaban subjek K8 pada soal nomor 2

Dari gambar, terlihat proses pengerjaan yang dilakukan siswa tidak begitu tepat. Siswa ceroboh dalam melakukan operasi pengerjaannya, sehingga mendapatkan hasil yang salah. Kesalahan seperti ini terjadi karena penulisan yang dilakukan siswa, seharusnya siswa bisa menuliskannya dalam perkalian saja. Dari kasus ini, rasanya juga sangat perlu untuk guru mengingatkan kembali kepada siswa mengenai konsep penjumlahan, perkalian dan pembagian pada pecahan. Materi operasi pecahan ini merupakan salah satu materi prasyarat mempelajari materi integral. Karena sifat-sifat pada operasi pecahan sangat diperlukan dalam menyelesaikan soal-soal integral.

Indikator 3: Menentukan integral tentu dari fungsi trigonometri dengan menggunakan aturan subtitusi. Pada indikator ini, guru memberikan sebuah fungsi trigonometri. Siswa diharapkan dapat menentukan integral tentu dari fungsi tersebut dengan menggunakan aturan subtitusi. 
Soal 3: Hasil dari $\int_{0}^{\frac{\pi}{2}} \sin x \cos ^{2} x d x$ adalah....

Berdasarkan analisis dari jawaban siswa, terdapat 4 orang yang salah dalam menjawab soal. Salah satu jawaban siswa yang salah dapat kita lihat pada gambar-3 di bawah ini.

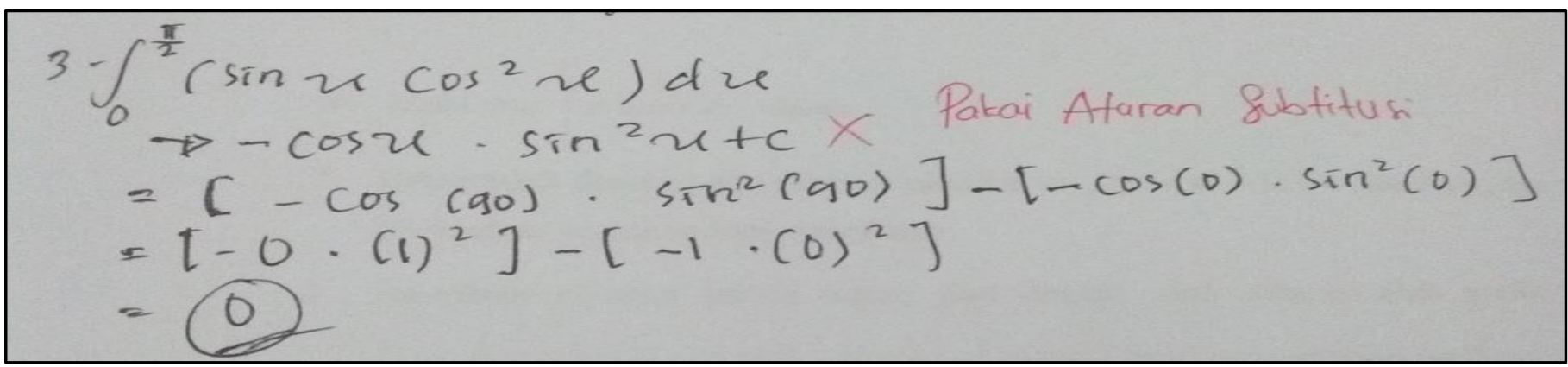

Gambar-3.

Jawaban subjek K6 pada soal nomor 3

Dari gambar di atas, terlihat kesalahan siswa terjadi karena siswa tidak menggunakan aturan yang benar dalam mengerjakannya. Siswa tidak bisa membedakan soal yang bisa dikerjakan dengan secara langsung diintegralkan dan mana yang harus menggunakan aturun khusus. Siswa seharusnya menggunakan aturan subtitusi untuk menyelesaikan tipe soal tersebut. Untuk itu guru diharapkan memberikan gambaran yang jelas kepada siswa bagaimana cara membedakan soal tersebut.

Indikator 4: Menentukan integral tentu dari fungsi trigonometri dengan menggunakan aturan integral parsial. Pada indikator ini, guru memberikan sebuah fungsi trigonometri. Siswadiharapkan dapat menentukan integral tentu dari fungsi tersebut dengan menggunakan aturan integral parsial.

Soal 4: Hasil dari $\int_{0}^{\frac{\pi}{2}} x \cos x d x$ adalah....

Dari 10 siswa yang mengerjakan, hanya 4 orang siswa yang menjawab benar. Salah satu jawaban siswa yang salah dapat kita lihat pada gambar-4 di bawah ini.

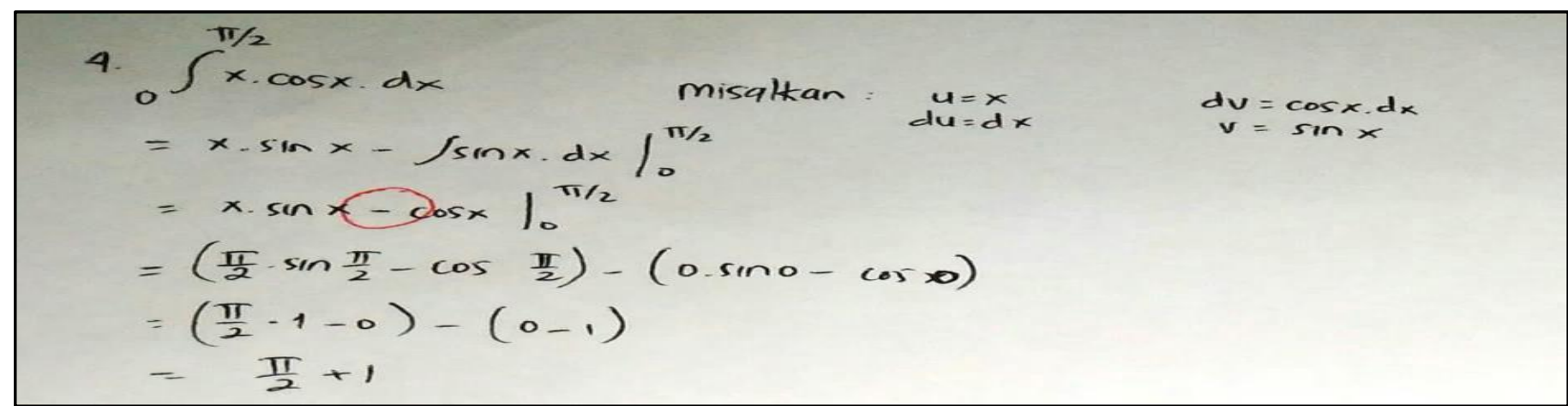

Gambar-4.

Jawaban subjek K7 pada soal nomor 4

Dari gambar-4, terlihat siswa ceroboh dalam melakukan operasi penyelesiannya. Siswa salah dalam pemberian tanda yang seharusnya positif tetapi menjadi negatif, karena integral dari sin $x$ adalah $-\cos x$. Dari kasus ini, siswa sebenarnya hanya perlu berhati-hati dan teliti dalam mengerjakan soal yang diberikan. 
Karena sebenarnya siswa mengerti konsepnya bahwa soal ini dikerjakan dengan menggunakan aturan integral parsial.

Indikator 5: Menghitung luas suatu daerah yang dibatasi oleh kurva dan sumbu-sumbu pada koordinat. Pada indikator ini guru memberikan suatu daerah yang dibatasi kurva dan garis-garis tertentu. Siswa diharapkan dapat menentukan luas daerah tersebut.

Soal5: Gambarlah daerah yang dibatasi oleh kurva $f(x)=x^{2}-3 x-4$, sumbu-y, dan garis $\mathrm{y}=-4$. Kemudian tentukan luas daerahnya.

Pada indikator ini, hanya ada 2 siswa yang menjawab dengan benar sampai kepada menentukan luasnya. Salah satu jawaban siswa yang salah dapat kita lihat pada gambar-5 berikut ini.

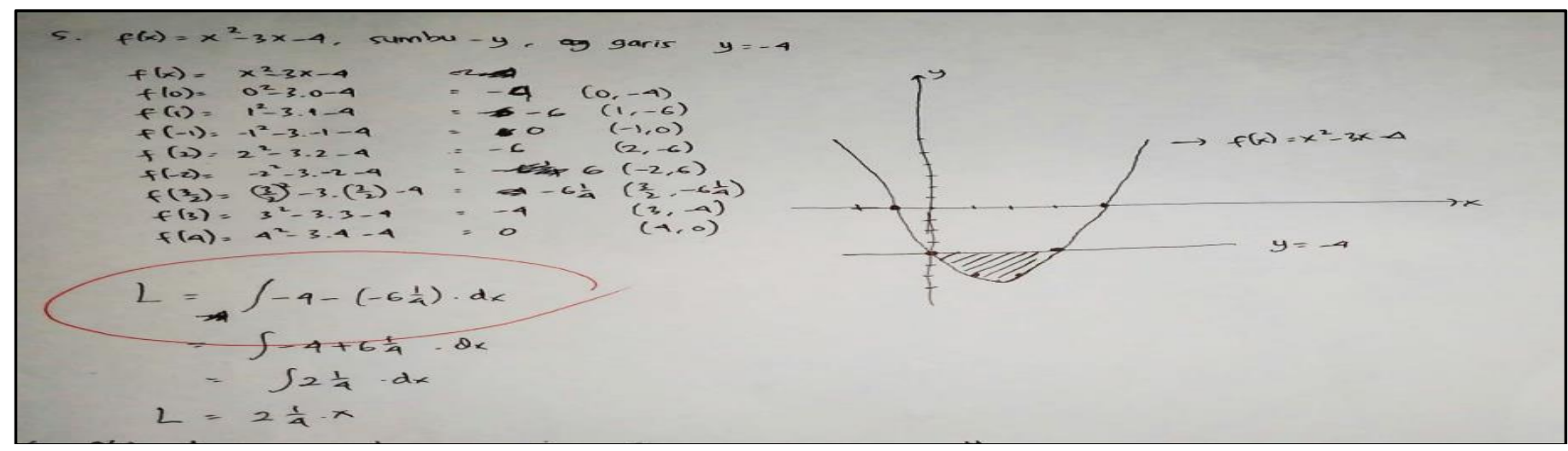

Gambar-5.

Jawaban subjek K2 pada soal nomor 5

Dari gambar, terlihat siswa sudah bisa membuat kurva ke dalam koordinat Cartesius. Siswa juga tepat meletakkan persamaan garis $\mathrm{y}=-4$. Tetapi siswa tidak paham bagaimana cara mencari luas daerah yang diarsir tersebut. Dilihat dari jawaban seluruh siswa, pada indikator ini terdapat 8 orang siswa yang salah dalam menjawab soal. Artinya indikator ini menjadi bagian yang sulit bagi siswa untuk dipahami. Untuk itu, diharapkan kepada guru untuk lebih memperbanyak memberikan soal-soal yang berhubungan dengan menentukan luas daerah.

Indikator 6 : Menghitung volume benda putar. Pada indikator ini guru memberikan sebuah daerah yang dibatasi oleh sebuah grafik dan garis-garis tertentu, siswa diharapkan dapat mencari volume benda putar dari daerah tersebut jika diputar mengelilingi sumbu $y$.

Soal 6: Tentukan volume benda putar, jika daerah yang dibatasi oleh grafik $f(x)=\frac{1}{4} x-2$, sumbu-x, garis $\mathrm{x}=0$, dan garis $\mathrm{x}=4$ diputar $360^{\circ}$ mengelilingi sumbu- $\mathrm{y}$.

Dari 10 siswa yang mengerjakan, tidak ada siswa yang menjawab dengan benar sampai tahap akhir dalam menentukan hasil volume benda putarnya, walaupun sudah banyak siswa yang mengerjakan sampai tahap menggambar grafiknya. Salah satu siswa yang mengerjakan dapat dilihat pada gambar-6 di bawah ini. 


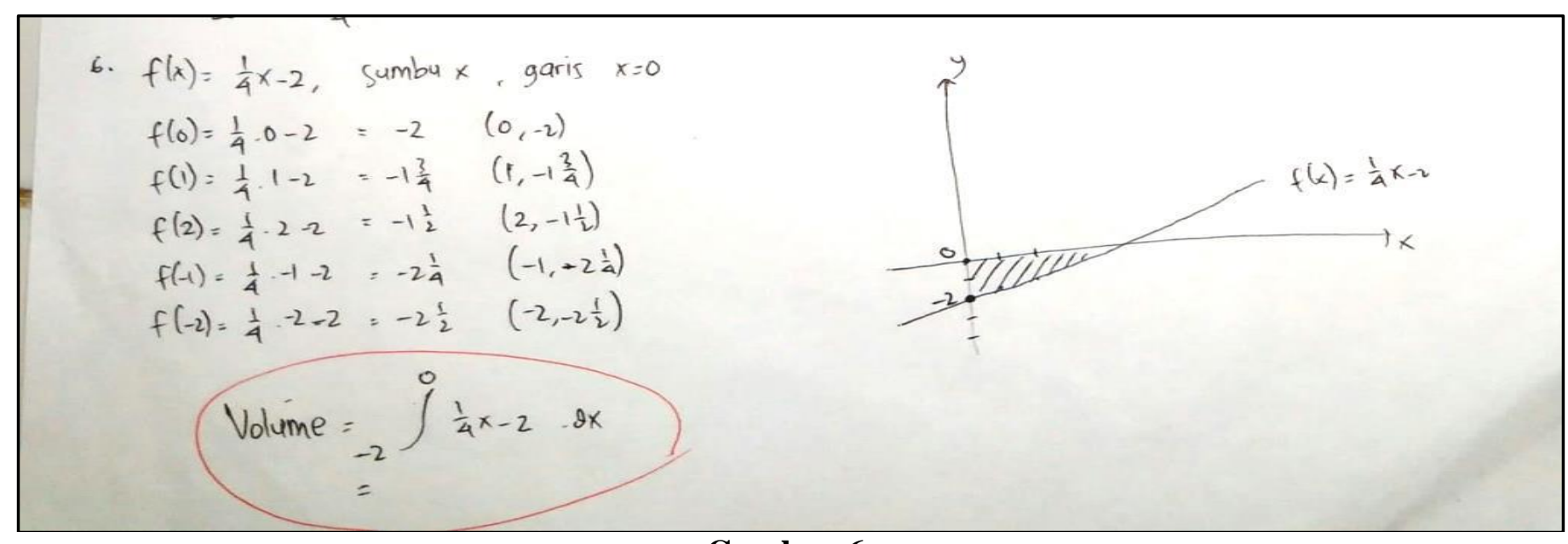

Gambar-6.

Jawaban subjek K9 pada soal nomor 6

Upaya agar siswa lebih memahami materi pada indikator menentukan volume benda putar ini, guru diharapkan mengaitkan materi ini dengan materi bangun ruang sisi lengkung dan memahami kembali aturan-aturan yang berlaku pada integral.

Selain mengetahui penyebab kesalahan siswa, peneliti juga melihat ketuntasan hasil belajar siswa dari ketercapaian KKM. KKM yang ditetapkan guru adalah 70. Ketercapaian KKM siswa pada integral ini dapat kita lihat pada tabel 4.

Tabel 4.

Analisis Ketuntasan Belajar Matematika Siswa

\begin{tabular}{|c|c|c|c|c|c|c|c|c|}
\hline \multirow{4}{*}{ Kode Siswa } & \multicolumn{6}{|c|}{ Nomor Soal } & \multirow{2}{*}{ Jumlah Skor } & \multirow{2}{*}{ Nilai Ujian } \\
\hline & 1 & 2 & 3 & 4 & 5 & 6 & & \\
\hline & \multicolumn{6}{|c|}{ Skor Maksimal Ideal } & \multirow{3}{*}{100} & \multirow{3}{*}{100} \\
\hline & 5 & 10 & 15 & 20 & 20 & 30 & & \\
\hline \multicolumn{7}{|c|}{ Skor yang Dicapai Siswa } & & \\
\hline K1 & 5 & 10 & 15 & 20 & 20 & 10 & 80 & 80.00 \\
\hline $\mathrm{K} 2$ & 5 & 10 & 15 & 20 & 20 & 10 & 80 & 80.00 \\
\hline $\mathrm{K} 3$ & 4 & 5 & 5 & 10 & 5 & 5 & 34 & 34.00 \\
\hline K4 & 5 & 10 & 15 & 20 & 10 & 10 & 70 & 70.00 \\
\hline K5 & 4 & 10 & 15 & 20 & 10 & 5 & 64 & 64.00 \\
\hline K6 & 4 & 10 & 3 & 20 & 5 & 2 & 44 & 44.00 \\
\hline K7 & 5 & 10 & 3 & 5 & 5 & 2 & 30 & 30.00 \\
\hline K8 & 4 & 5 & 3 & 5 & 5 & 5 & 27 & 27.00 \\
\hline K9 & 5 & 10 & 15 & 5 & 5 & 2 & 42 & 42.00 \\
\hline K10 & 5 & 8 & 15 & 20 & 15 & 10 & 73 & 73.00 \\
\hline
\end{tabular}

Dari tabel di atas, terlihat bahwa persentase jumlah siswa yang mencapai KKM tidak lebih dari 50\%. Artinya, pencapaian siswa pada materi ini tergolong rendah. Tidak ada siswa yang mendapatkan nilai sempurna. Nilai tertinggi yang diperoleh siswa yaitu 80 (skala 100). Jika dilihat dari nilai yang diperoleh siswa pada setiap indikator soal yang diberikan, maka nilai pada indikator 6 merupakan nilai dengan skor terendah yang diperoleh siswa. Tidak ada siswa yang menjawab dengan benar pada indikator ini.

\section{SIMPULAN}

Kesimpulan yang dapat diambil dari analisis kesalahan siswa pada materi integral yang diujikan di MA Khairul Ummah Inhu ini adalah:

1) Dari 4 jenis kesalahan yang dilakukan siswa, kesalahan yang paling dominan dilakukan siswa adalah kesalahan konsep sebesar $36,7 \%$, diikuti dengan kesalahan operasi sebesar $20 \%$, kesalahan prinsip sebesar 5\%, dan kesalahan fakta sebesar 3,3\%. 
2) Faktor penyebab terjadinya kesalahan siswa yaitu tidak memahami sifat-sifat pada integral secara baik serta kurang memahami konsep materi prasyarat seperti konsep operasi penjumlahan dan perkalian pecahan, serta kurang teliti dalam melakukan operasi penyelesaian soal.

3) Hasil ketuntasan belajar siswa pada materi ini masih tergolong rendah.

Dari penelitian yang telah dilakukan, peneliti ingin memberikan saran kepada setiap guru agar selalu memberikan inovasi dan strategi yang tepat pada setiap pembelajaran sehingga kesalahan siswa dalam menyelesaikan soal dapat diminimalkan.

\section{DAFTAR PUSTAKA}

Haryati,T., Suyitno, A., \& Junaedi, I. (2016). Analisis kesalahan siswa smp kelas VII dalam menyelesaikan soal cerita pemecahan masalah berdasarkan operasi Newman. Unnes Journal of Mathematics Education, 5(1), 8-15. http://journal.unnes.ac.id/sju/index.php/ujme

Lestari, L.A., Suharto, \& Fatahillah, A. (2016). Analisis Pengaruh Disposisi Matematis terhadap Hasil Belajar Materi Integral Tak Tentu Siswa Kelas XII IPA 2 SMAN 4 Jember. Jurnal Edukasi, 3(1), 4043

Oktavia, A \& Khotimah, R.P. (2016). Analisis Kesulitan Mahasiswa dalam Menyelesaikan Persamaan Differensial Tingkat Satu. Koferensi Nasional Penelitian Matematika dan Pembelajarannya, Universitas Muhammadiyah Surakarta.

Ramdani, Y. (2012). Pengembangan Instrumen dan Bahan Ajar Untuk Meningkatkan Kemampuan Komunikasi, Penalaran, dan Koneksi Matematis dalam Konsep Integral. Jurnal Penelitian Pendidikan, 13(1), 44-52

Riyanto, B \& Siroj, R.A. (2011). Meningkatkan Kemampuan Penalaran dan Prestasi Matematika dengan Pendekatan Konstruktivisme pada Siswa Sekolah Menengah Atas. Jurnal Pendidikan Matematika, $5(2), 111-128$

Rumasoreng, M.I \& Sugiman. (2014). Analisis Kesulitan Matematika Siswa SMA/MA dalam Menyelesaikan Soal Setara UN di Kabupaten Maluku Tengah. Jurnal Riset Pendidikan Matematika, $1(1), 22-34$

Umam, M.D. (2014). Analisis Kesalahan Siswa dalam Menyelesaikan Soal Cerita Matematika Materi Operasi Hitung Pecahan. MATHEdenusa jurnal ilmiah pendidikn matematika, 3(3), 131-134 